\title{
sciendo
}

Folia Oeconomica Stetinensia

Volume 20 (2020) Issue 1

DOI: $10.2478 /$ foli-2020-0012
WYDZIAL NAUK EKONOMICZNYCH I ZARZA¿DZANIA

\section{THE ROLE OF BARRIERS TO THE ACTIVITY OF INDUSTRIAL ENTERPRISES IN THE EVALUATION OF THE BUSINESS TENDENCY IN POLAND}

\author{
Maria Kaźmierska-Zatoń, Ph.D. \\ Stefan Batory State University \\ Collegium of Socio-Economics \\ Institute of Economics and Management \\ Batorego 64C, 96-100 Skierniewice, Poland \\ e-mail: zaton@poczta.onet.pl \\ ORCID: 0000-0003-0366-6628 \\ Wojciech Zatoń, Ph.D. \\ University of Lodz \\ Faculty of Economics and Sociology \\ Department of Central Banking and Financial Intermediation \\ Rewolucji 1905 r. no. 39, 90-214 Lodz, Poland \\ e-mail:wojciech.zaton@uni.lodz.pl \\ ORCID: 0000-0002-7566-187X
}

Received 17 October 2019, Accepted 31 March 2020

\begin{abstract}
Research background: Surveys of entrepreneurs regarding the assessment of conditions for conducting business activity are carried out by several institutions. They focus on business climate indicators but in parallel they report on numerous barriers to economic activity. The paper examines the barriers that hinder business operations to manufacturing enterprises in Poland.

Purpose: The purpose of the paper is to analyse the barriers to business activity and their role in entrepreneurs' assessment of their general economic situation. It has been hypothesized that statistically significant barriers to economic activity that affect the assessment of the general economic situation by entrepreneurs can be determined.

Research methodology: The analysis was based on the Central Statistical Office data from the business tendency survey in manufacturing enterprises spanning the period 2003-2019, broken down into groups of small, medium-sized and large enterprises. Correlation measures and regression models were used.

Results: The results allow indicating several barriers that have a significant impact on the assessment of the current economic situation by entrepreneurs. This impact varies depending on the size of the enterprise. No significant relationship was found between the barriers and the assessment of the expected economic situation.
\end{abstract}


Novelty: The paper contributes to studies on business tendency surveys. It develops a detailed analysis of the barriers to economic activity, takes into account the size of enterprises and examines the influence of business barriers on the assessment of the economic situation by entrepreneurs.

Keywords: business tendency survey, barriers to economic activity, business climate indicator, enterprise, economic situation

JEL classification: C10, C20, L2, L6

\section{Introduction}

The economic activity of enterprises is a key element of the functioning of the market economy (Gruszecki, 2002) and the processes of economic development of a country as well as of the individual enterprises which are interdependent (Komorowski, 2012). In order to act effectively, enterprises must monitor changes occurring in their environment and respond to them appropriately by adjusting their own strategies. Identifying barriers to business operations is therefore important both on the part of these economic entities and on the part of macroeconomic decision makers. Removing or mitigating entrepreneurship barriers can be as effective as using the right macroeconomic policy tools. While the influence of the state on the barriers created by the market is small, it can be considerable in eliminating institutional barriers, perceived as much more annoying by entrepreneurs (Adamowicz, Jóźwiak, 2008). It is particularly important in relation to small and medium-sized enterprises (cf. e.g. Krezymon, 2018; Leoński, 2014; Ziemba, Świeszczak, 2013).

The surveys of entrepreneurs regarding the assessment of conditions for conducting business activity are carried out by many institutions. They vary in scope, frequency and complexity. Data from these studies are microeconomic in nature, but refer to the macroeconomic situation. After aggregation they are an important source of information used for predicting the economic situation in Poland. In this context, the quality and consistency of these data are therefore important.

In the surveys, the respondents are often asked about both an overall assessment of the business conditions and about the barriers to activity (e.g. NBP, 2019; GUS, 2019; Konfederacja Lewiatan, 2018, 2019; Grant Thornton, 2019; ZPP, 2018a, 2018b). The reports show that in the last few years in Poland, despite a constantly improving economic climate for entrepreneurs, there are still numerous barriers to activity and development. Therefore, the following questions 
can be formulated: to what extent the perception of difficulties of different ways of doing business in Poland influences opinions on the general economic situation; are the respondents' answers in this regard consistent, showing a complex view of their situation in the changing environment? The paper attempts to answer these questions.

Issues regarding the assessment of the economic situation by entrepreneurs and their opinions on obstacles and barriers to doing business in Poland are present both in the reports of institutions monitoring the activity of enterprises and in scientific publications. E. Adamowicz and J. Jóźwiak (2008) attempted to describe the adaptation of enterprises to changes occurring in their environment, in particular the reaction of enterprises to signals coming from the market and sent by the state, using data from the IRG SGH business climate survey for 1997-2007. In turn, J. Oryńczak, M. Święcka, K. Walkowska and I. Zagoździńska (2008) analysed the intensity of the perception of business barriers by entrepreneurs in various sectors of the economy (manufacturing, construction, trade, and services), based on data from the Central Statistical Office (CSO) business tendency survey for 1993-2007. The descriptions of the results of sectoral surveys on this subject can be found, for example, in: J. Fazlagić, R. Skikiewicz (2018) - analysis of barriers to doing business against the background of the economic situation in selected sections of the service sector by voivodeship (data from the CSO business tendency survey for 2011-2016) and P. Mikołajczyk, R. Skikiewicz (2014) - assessment of the impact of barriers hindering activity in the construction sector on the financial situation of the enterprises (data from the CSO business tendency survey, national and voivodeships crosssection for 2011-2013).

In extension to the aforementioned studies, the authors of this paper carry out a more detailed analysis, take into account the size of enterprises and verify the hypothesis (using correlation and regression methods) that the perception of business barriers by entrepreneurs has a significant impact on their assessment of the economic situation.

The purpose of the paper is to analyse the barriers to business activity and their role in the assessment of the general economic situation by entrepreneurs in the manufacturing sector in Poland. It has been hypothesized that statistically significant barriers to economic activity that affect the assessment of the general economic situation by entrepreneurs can be determined. The first step was to analyse and describe the scale and variability of different barriers - using descriptive statistics and graphical trend analysis. Next, the impact of these barriers on the assessment of the current and expected economic situation was examined - in this regard a correlation analysis and regression models were applied. 
The analysis was based on data of the CSO business tendency survey in manufacturing enterprises for the period from the first quarter of 2003 to the second quarter of 2019 (66 observations), ${ }^{1}$ broken down into groups of small, medium-sized and large enterprises.

\section{Data used in the study}

The CSO business tendency survey covers entities conducting business in the manufacturing sector classified according to the Polish Classification of Activities (PKD 2007) to section C (GUS, 2018). Under examination are enterprises employing 10 or more people, divided into size classes by the number of employees: from 10 to 49 people (small enterprises), from 50 to 249 people (medium-sized enterprises), 250 and more people (large enterprises). The survey is conducted in 3,498 units - all large enterprises in the sector and 10\% of the group of small and medium-sized ones. The answers are delivered by the directors of the surveyed companies.

In this article two types of simple business climate indicators were used: these concerning the barriers to hindering the activity and those expressing the assessment of the company's general economic situation (current and expected).

The barriers' indicators are built on the answers to the following question: "What are the most important barriers currently restricting your business?". ${ }^{2}$ The respondents have the opportunity to indicate multiple items from the list of 15 proposed entries: no barriers, insufficient domestic demand, insufficient foreign demand, shortage of labour, shortage of skilled labour, shortage of raw materials, materials and semi-finished products (due to non-financial reasons), lack of appropriate equipment, shortage of energy, cost of labour, financial problems, high payments to state revenue, competitive imports, unclear legal regulations, uncertainty of economic environment, and others. The indicators are calculated as the percentage share of entities indicating a given barrier in the total number of all entities reporting the occurrence of any barrier. They can take values in the range from 0 to 100 .

The business climate indicators regarding the assessment of the general economic situation (current and expected, separately) of the company are the results of the answers to two questions: "What is the current general economic situation of your company?" and "How do you think the general economic situation of your company will change in the next three

\footnotetext{
1 Data of the last month of each quarter were used. The business climate indicators are published monthly but until 2018 data on the barriers to activity were gathered and published only every quarter, in March, June, September and December.

2 https://stat.gov.pl/obszary-tematyczne/koniunktura/koniunktura/koniunktura-w-przetworstwie-przemyslowymbudownictwie-handlu-i-uslugach-2000-2019-kwiecien-2019,4,24.html.
} 
months?"3 The respondents answer each of these questions by choosing one of three options given: good, satisfactory, bad (for the first question) and: will improve, remain unchanged, get worse (for the second question). The simple business climate indicators (concerning current and expected economic situations) are calculated as the balance of a percentage of positive replies over a percentage of negative ones in the total number of answers. So only two extreme cases are finally taken into account. The balance may range from -100 (extremely unfavourable situation) to +100 (extremely favourable situation). The composite general business climate indicator is then calculated as the arithmetic average of two simple business climate indicators (the balances of answers about the current and expected economic situation of an enterprise).

\section{Barriers to economic activity, economic situation indicators - preliminary analysis}

The barriers included in the CSO business tendency survey can be divided into the following areas:

a) demand barriers - insufficient domestic demand, insufficient foreign demand, competitive imports;

b) supply barriers - shortage of labour, shortage of skilled labour, shortage of raw materials, materials and semi-finished products (due to non-financial reasons), lack of appropriate machinery, shortage of energy;

c) financial and legal barriers - financial problems, cost of labour, high payments to state revenue, unclear legal regulations, uncertainty of economic environment.

The analysed data indicate that for each barrier the percentage of enterprises reporting it shows changes of varying intensity and direction. For most barriers trends are decreasing with the exception of the shortage of labour (total and skilled) and cost of labour where trends are increasing. These trends were distorted only during the economic crisis (2008-2009). The most and the least noticeable barriers in each of three specified areas and by the enterprise size are depicted in Figure 1, while the average rate of change in the perception of all barriers (included the case when entrepreneurs declare there are no barriers - "NONE") is illustrated in Figure 2. Table 1 contains basic descriptive statistics of the analysed variables.

Among the demand barriers, the largest number of enterprises indicated insufficient domestic demand. The maximum values (reached in the second quarter of 2003) were 77.3, 77.9 and 70.5 in groups of small, medium-sized and large enterprises, respectively. In subsequent periods of analysis, these values fell by 0.5 on average from quarter to quarter. In the second

\footnotetext{
3 Ibidem.
} 
quarter of 2019 (end of data sample), the importance of insufficient domestic demand was definitely smaller: only 29.2 for small enterprises, 28.9 for medium-sized enterprises and 30.1 for large enterprises.
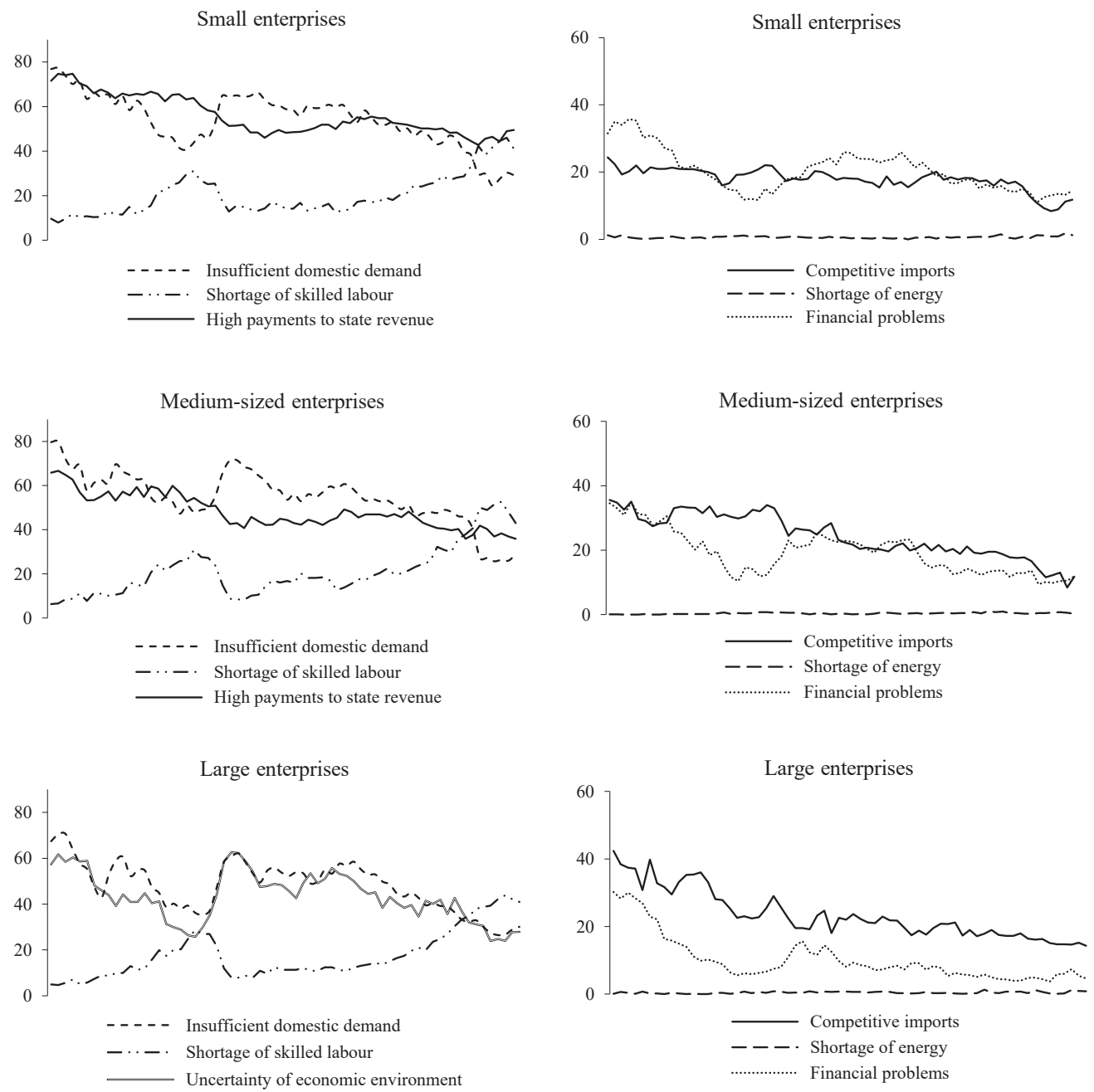

Figure 1. The most (left column) and least (right column) noticeable barriers to activity in enterprise groups as a percentage of enterprises declaring particular barriers, in the period 2003.1-2019.2 (x-axis)

Source: CSO, https://stat.gov.pl/obszary-tematyczne/koniunktura/koniunktura/koniunktura-w-przetworstwie-przemysl owym-budownictwie-handlu-i-uslugach-2000-2019-kwiecien-2019,4,24.html. 


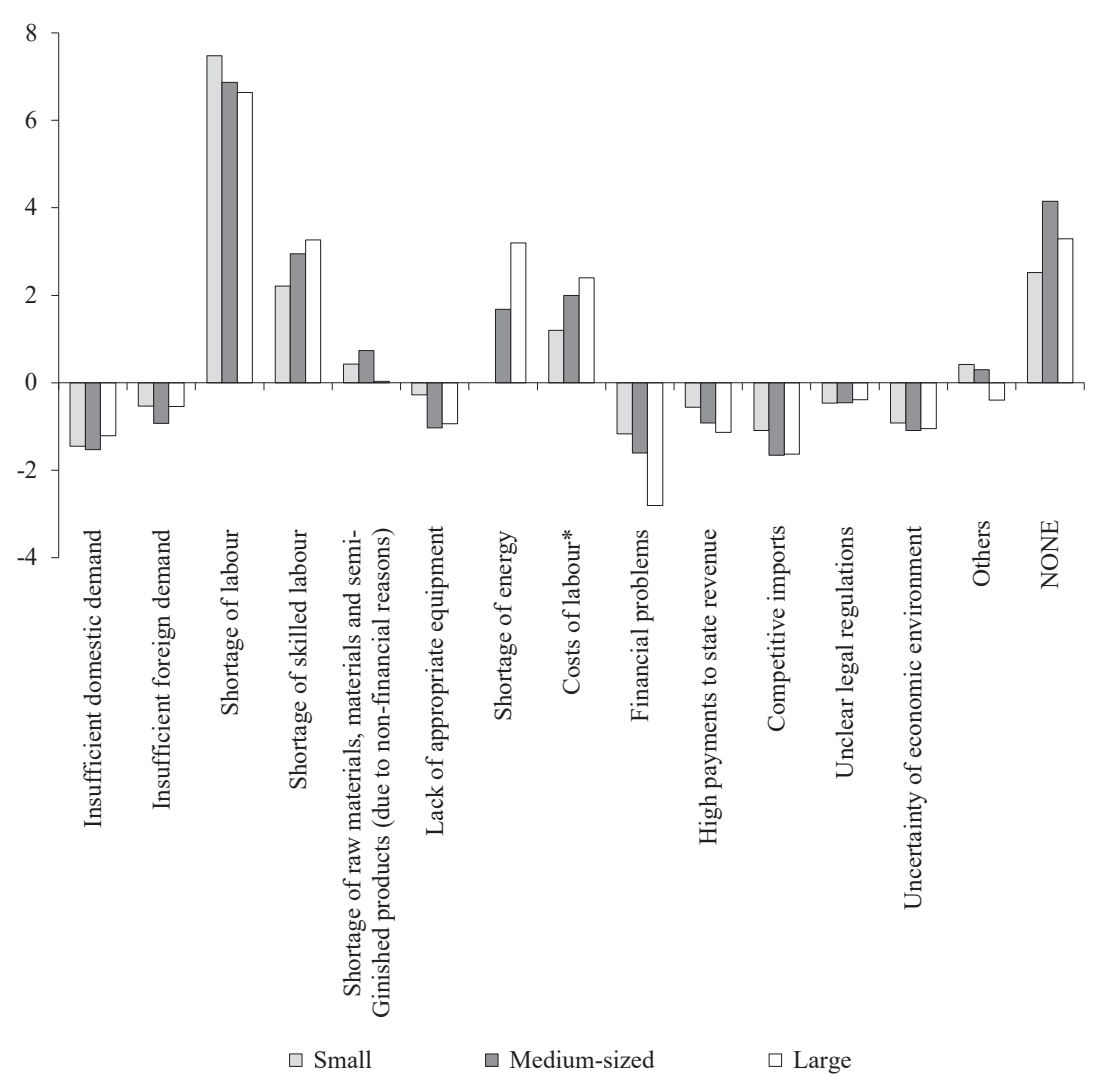

Note: * calculations based on data for the period 2010.1-2019.2.

Figure 2. The average rate of change in the perception of the barriers in enterprise groups during the period 2003.1-2019.2 (\%)

Source: authors' calculations based on CSO data.

In the area of supply barriers, the most important one was the shortage of skilled labour in the worst period (fourth quarter of 2018) $46 \%$ of small, $52.7 \%$ of medium-sized and $43.8 \%$ of large enterprises reported this inconvenience. The shortage of labour was mentioned in the second place. The indications for these two barriers were growing according to non-linear trends, at a medium-term growth from 6.5 to $7.6 \%$ (depending on the size of an enterprise) and 2.2 to $3.3 \%$ for the shortage of labour and the shortage of skilled labour, respectively. Other supply barriers were definitely less important with their intensity oscillating in the range 8-22 for the shortage of raw materials, materials and semi-finished products, 12-21 for the lack of appropriate equipment and even not exceeding 2 for the shortage of energy. 
Table 1 Basic descriptive statistics of the variables

\begin{tabular}{|c|c|c|c|c|c|c|c|c|c|c|}
\hline \multirow[b]{3}{*}{ Name } & \multirow[b]{3}{*}{ Denotation } & \multicolumn{9}{|c|}{ Enterprise size group } \\
\hline & & \multicolumn{3}{|c|}{ small } & \multicolumn{3}{|c|}{ medium-sized } & \multicolumn{3}{|c|}{ large } \\
\hline & & 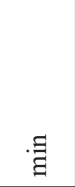 & 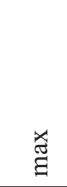 & 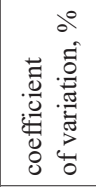 & 寻 & $\stackrel{\varpi}{ٌ}$ & 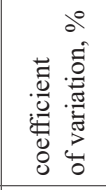 & 寻 & $\stackrel{×}{\rightleftarrows}$ & 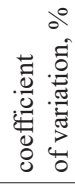 \\
\hline Insufficient domestic demand & IDD & 24.4 & 77.3 & 22.6 & 25.7 & 79.9 & 22.2 & 26.5 & 70.6 & 25.4 \\
\hline Insufficient foreign demand & IFD & 13.4 & 29.2 & 18.0 & 18.3 & 53.8 & 10.4 & 19.9 & 60.2 & 9.8 \\
\hline Shortage of labour & SL & 0.3 & 36.7 & 121.9 & 0.5 & 45.7 & 110.6 & 0.2 & 39.3 & 115.2 \\
\hline Shortage of skilled labour & SSL & 7.9 & 46.0 & 46.4 & 6.3 & 52.7 & 43.8 & 4.7 & 43.8 & 53.0 \\
\hline $\begin{array}{l}\text { Shortage of raw materials, } \\
\text { materials and semi-finished } \\
\text { products (due to non-financial } \\
\text { reasons) }\end{array}$ & SRM & 2.0 & 8.0 & 29.4 & 4.1 & 14.0 & 19.9 & 3.6 & 21.6 & 15.4 \\
\hline Lack of appropriate equipment & LAE & 5.0 & 16.2 & 19.0 & 7.0 & 21.2 & 14.8 & 4.7 & 11.7 & 26.4 \\
\hline Shortage of energy & SE & 0.0 & 1.8 & 55.1 & 0.0 & 1.1 & 89.0 & 0.0 & 1.3 & 78.5 \\
\hline Costs of labour* & $\mathrm{CL}$ & 44.1 & 68.5 & 10.1 & 29.5 & 63.1 & 12.3 & 17.7 & 44.0 & 18.4 \\
\hline Financial problems & $\mathrm{FP}$ & 10.9 & 35.8 & 31.1 & 9.4 & 34.9 & 33.1 & 3.7 & 30.2 & 62.5 \\
\hline High payments to state revenue & HP & 42.7 & 74.7 & 15.5 & 35.9 & 66.7 & 18.0 & 27.2 & 66.1 & 21.7 \\
\hline Competitive imports & $\mathrm{CI}$ & 8.4 & 24.4 & 18.0 & 8.4 & 35.6 & 13.3 & 14.3 & 42.4 & 13.8 \\
\hline Unclear legal regulations & ULR & 26.3 & 48.4 & 14.8 & 24.6 & 46.4 & 15.1 & 28.4 & 51.3 & 14.2 \\
\hline $\begin{array}{l}\text { Uncertainty of economic } \\
\text { environment }\end{array}$ & UEE & 28.6 & 68.9 & 20.4 & 23.9 & 62.6 & 23.2 & 21.8 & 66.1 & 24.2 \\
\hline Others & $\mathrm{O}$ & 2.7 & 10.1 & 23.5 & 3.9 & 13.0 & 17.2 & 6.4 & 21.2 & 14.2 \\
\hline No barriers & NONE & 1.8 & 12.0 & 34.8 & 0.4 & 13.2 & 35.3 & 1.7 & 18.6 & 22.8 \\
\hline $\begin{array}{l}\text { Current general economic } \\
\text { situation of the enterprise }\end{array}$ & CURRENT & -31.7 & 19.5 & -141.7 & -21.8 & 23.1 & -1012.1 & -13.9 & 43.8 & 60.4 \\
\hline $\begin{array}{l}\text { Expected general economic } \\
\text { situation of the enterprise }\end{array}$ & EXPECTED & -22.4 & 16.7 & 668.2 & -24.6 & 29.2 & 95.6 & -14.8 & 34.5 & 57.4 \\
\hline
\end{tabular}

Notes: calculations based on data for the period 2003.1-2019.2; ${ }^{*}$ - calculations for the period 2010.1-2019.2.

Source: authors' calculations based on CSO data.

The scale of financial and legal barriers was similar to that for demand barriers. The highest numbers were recorded for high payments to state revenue: 43-75 among small enterprises, 3667 medium-sized and 27-66 large ones during the whole period. Particular attention should be paid to costs of labour. Data on this barrier have only been available since 2010 and have shown its rapidly growing role in business operations. At the beginning, in the first quarter of 2010, this barrier was at the level of 17.7 for the large enterprises and at 44 for small ones. In the last period of the analysis (second quarter of 2019) these numbers were already at 43.9 and 68.5 levels, respectively. Within this group of barriers, financial problems were least noticeable. 
It is worth noting that, despite the presence of numerous indicated barriers (some with high intensity), the group of enterprises pointing at no barriers was steadily growing in the analyzed period. On average (for all size classes) the percentage of these enterprises rose from 1.4 to $12.5 \%$ - see Figure 3 .

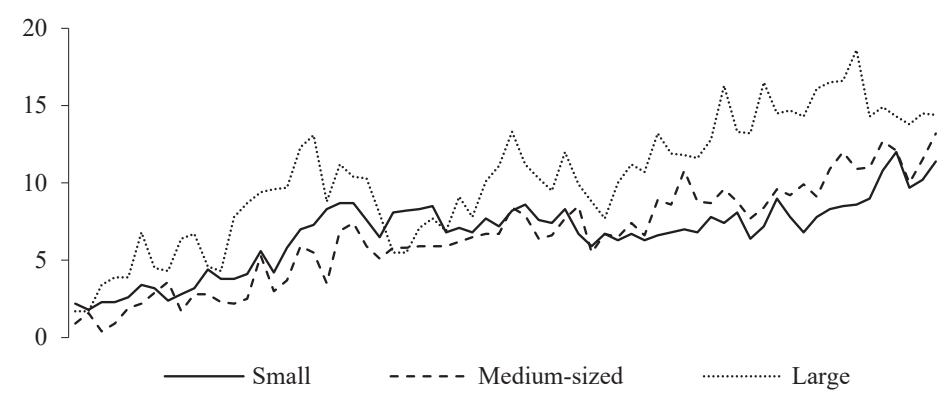

Figure 3. Percentage of enterprises declaring no barriers to business activity, by enterprise size, in the period 2003.1-2019.2 (x-axis)

Source: CSO data, https://stat.gov.pl/obszary-tematyczne/koniunktura/koniunktura/koniunktura-w-przetworstwie-prze myslowym-budownictwie-handlu-i-uslugach-2000-2019-kwiecien-2019,4,24.html.

The composite general business climate indicator can be used to determine the synthetic picture of the state of the economy. However, to deepen the analysis, we focus on its components, simple business climate indicators, because they may show the differences between the assessments of the current and the expected economic situations made by the entrepreneurs (see Figure 4). In the whole analysed period, the current economic situation in

CURRENT

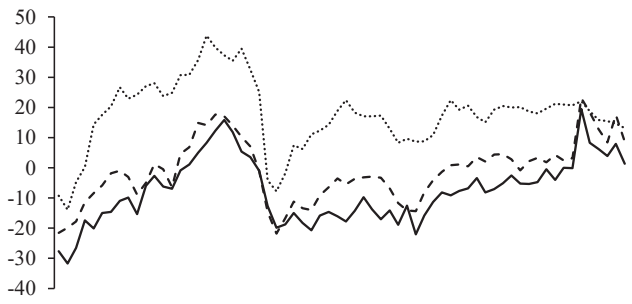

EXPECTED

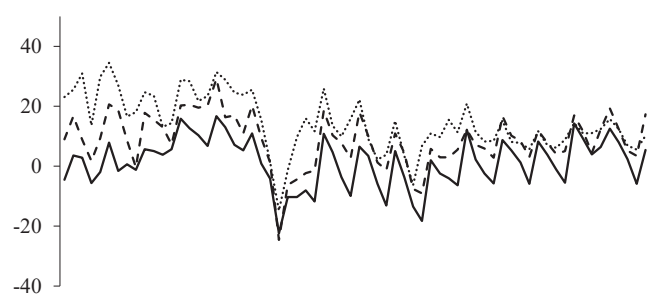

- Small - - - - - Medium-sized Large

Figure 4. Values of indicators of the current (CURRENT) and the expected (EXPECTED) general economic situations in enterprises, by enterprise size, in the period 2003.12019.2 (x-axis)

Source: CSO data, https://stat.gov.pl/obszary-tematyczne/koniunktura/koniunktura/koniunktura-w-przetworstwie-prze myslowym-budownictwie-handlu-i-uslugach-2000-2019-kwiecien-2019,4,24.html. 
the manufacturing sector (measured by the indicator of the current general economic situation) was estimated as quite stable with minor trends within specified ranges. However, its average level was dependent on the size of an enterprise - it was positive $(+17.7)$ for large entities and negative for medium-sized $(-1.1)$ as well as for small ones (-7.6). On the other hand, the indicator of the expected general economic situation of the enterprise showed much more volatility but in narrower ranges, similar for all size groups of enterprises. Its average value was slightly above zero.

\section{Barriers to economic activity, economic situation indicators - correlation and regression analysis}

The graphical analysis of the indicators of the current and the expected general economic situation and the barriers point to the frequent occurrence of non-linear relationships between them and discovers some outliers. Therefore, Spearman's rank correlation coefficient was applied to measure the strength and direction of the relationships between these variables. It was also used to measure the correlations between different barriers.

Within the barriers there are some strong $( \pm 0.75$ to \pm 0.90$)$ correlations, similar in all three group of enterprises. As examples of such relationships it is worth pointing out the following pairs: insufficient domestic demand and insufficient foreign demand, insufficient domestic demand and financial problems, uncertainty of economic environment and shortage of labour.

The correlation coefficients between most of the barriers ${ }^{4}$ and the indicators of the current and the expected general economic situation are presented in Figure 5. In case of the current economic situation many of the coefficients are significant (at a 5\% level). There are few exceptions. The exception common to enterprises of all sizes, is the relationship involving the barrier representing high payments to state revenue. It is particularly interesting that despite the high (at about a 40-50 level) intensity of this barrier, its correlation with the assessment of the current economic situation is weak and statistically insignificant. It means that this barrier permanently hampers the economic activity. Other insignificant relationships occur between the indicator of the current general economic situation and: unclear legal regulations for small enterprises; lack of appropriate equipment for medium-sized enterprises; shortage of energy and competitive imports in case of large entities. The strength and direction of the relationships vary according to both the barrier and the size of the enterprise. The barriers most strongly correlated with the indicator of the current general economic situation are: insufficient demand,

\footnotetext{
${ }^{4}$ Barrier representing cost of labour was excluded from the analysis due to the low number of observations.
} 
financial problems, uncertainty of the general situation and shortage of labour (total and skilled). The negative sign of correlations in relationships involving the first three of the barriers mentioned above is straightforward - increase in the intensity of these barriers is an obvious factor that limits economic activity. As to the shortage of labour, it grows when the economic situation improves (demand causes production to expand thus the need for new employees makes the labour market shrink), hence the positive correlation of this barrier with the indicator of the current general economic situation. The positive (but much weaker) correlation is also observed in the case of unclear legal regulations. This shows that the problem with inconsistent and unclear regulations is more perceived and experienced by entrepreneurs especially then when they are expanding their economic activity.

The strength of the correlation is similar for most barriers in groups of small and mediumsized enterprises, and relatively smaller for large entities.

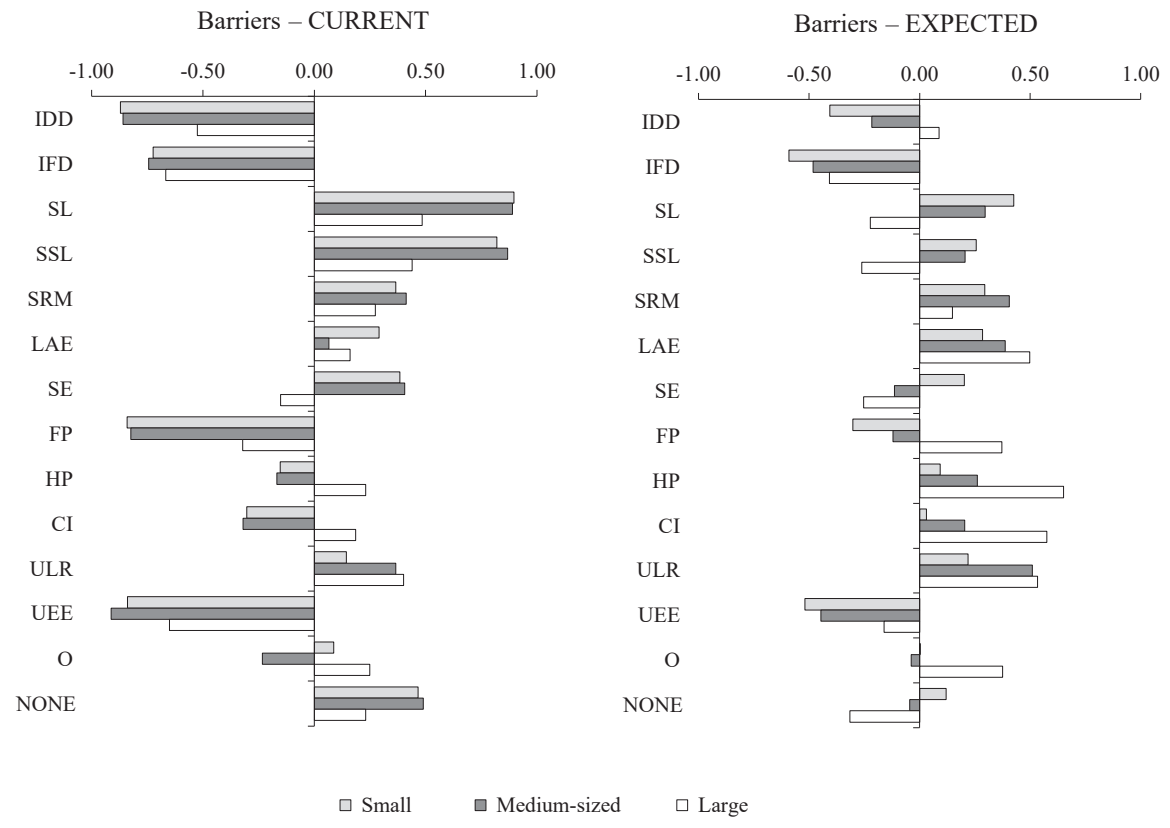

Figure 5. Spearman's rank correlation coefficients by enterprise size

Source: authors' calculations based on CSO data.

The correlation analysis demonstrated that the perception of business barriers by entrepreneurs is much more translated into their assessments concerning the current than the expected general economic situation. Thus, in the next stage of the study, regression analysis, 
attention was focused on the relationship between the indicator of the current general economic situation and the barriers.

In the first step, the stationarity of the analysed data series was examined. The augmented Dickey-Fuller (ADF) unit root test and the Kwiatkowski, Phillips, Schmidt, Shin (KPSS) stationarity test ${ }^{5}$ were used. The conclusions of both tests concerning the stationarity of data series were consistent, with very few exceptions. In the vast majority of cases, the variables in levels turned out to be non-stationary, while their first differences were stationary. ${ }^{6}$ Due to such results, it was decided to build regression models for variables in first differences. ${ }^{7}$

In order to verify the hypothesis about the occurrence of statistically significant barriers to economic activity that affect the assessment of the general current economic situation by entrepreneurs, the parameters of two regression models were estimated. The assumptions for the construction of these models were as follows:

- the dependent variable was the assessment (indicator) of the current general economic situation,

- the independent variables were the barriers to activity that were most strongly correlated with the assessment of the current general economic situation,

- data series in the first differences of the aforementioned variables were used,

- both models were applied to all three size groups of enterprises.

The results of regressions are shown in (Table 2). The common barriers in both models are financial problems and unclear legal regulations. In both cases insufficient demand, domestic or foreign, was also taken into account. The barriers that occur interchangeably in two models are: shortage of skilled labour (model 1) and uncertainty of economic environment (model 2).

It can be seen that the perception of insufficient market demand affects the assessment of the economic situation to a similar extent in each group of enterprises. However, it is not the case as to the unclear legal regulations, where one can observe quite a large variation in the analysed impact. The intensity of this barrier has the strongest influence on the assessment of the economic situation in small enterprises and the least impact in large entities. The same applies to the barrier representing financial problems.

\footnotetext{
5 In the ADF test, the null hypothesis assumes the occurrence of a unit root (the series is not stationary), and its rejection indicates the series is stationary. In the case of the KPSS test, the null hypothesis is that the series is stationary, while the alternative hypothesis indicates the presence of a unit root. For the ADF test, the optimal lag length selection was based on the Akaike criterion, assuming 4 as the maximum length. The same lag length was then used in the KPSS test. For both tests, the model with constant and without trend was applied.

${ }^{6}$ At the 0.05 significance level.

7 Due to the non-stationarity of variables in levels, the cointegration relationships between several barriers to activity and the assessment of the current economic situation were also examined but they were not confirmed..
} 
Table 2. Regression results

\begin{tabular}{|c|c|c|c|c|c|c|}
\hline \multirow{2}{*}{$\begin{array}{l}\text { Enterprise size } \\
\text { group }\end{array}$} & \multicolumn{5}{|c|}{ Model 1} & \multirow{2}{*}{$\mathrm{R}^{2}$} \\
\hline & intercept & $\begin{array}{c}\text { insufficient } \\
\text { foreign demand }\end{array}$ & $\begin{array}{c}\text { shortage of skilled } \\
\text { labour }\end{array}$ & $\begin{array}{l}\text { financial } \\
\text { problems }\end{array}$ & $\begin{array}{l}\text { unclear legal } \\
\text { regulations }\end{array}$ & \\
\hline Small & $\begin{array}{l}-0.023 \\
(0.399)\end{array}$ & $\begin{array}{c}-0.591 * * \\
(0.252)\end{array}$ & $\begin{array}{c}0.700 * * * \\
(0.164)\end{array}$ & $\begin{array}{c}-0.857 * * * \\
(0.233)\end{array}$ & $\begin{array}{c}0.843 * * * \\
(0.167)\end{array}$ & 0.65 \\
\hline Medium-sized & $\begin{array}{c}0.026 \\
(0.377) \\
\end{array}$ & $\begin{array}{c}-0.672 * * * \\
(0.170)\end{array}$ & $\begin{array}{l}0.289 * \\
(0.153)\end{array}$ & $\begin{array}{c}-0.611 * * * \\
(0.179)\end{array}$ & $\begin{array}{c}0.661 * * * \\
(0.155)\end{array}$ & 0.68 \\
\hline \multirow[t]{3}{*}{ Large } & $\begin{array}{l}-0.164 \\
(0.484)\end{array}$ & $\begin{array}{c}-0.706 * * * \\
(0.117) \\
\end{array}$ & $\begin{array}{c}0.328 \\
(0.227) \\
\end{array}$ & $\begin{array}{c}-0.577^{*} \\
(0.300)\end{array}$ & $\begin{array}{c}0.199 \\
(0.165)\end{array}$ & 0.58 \\
\hline & \multicolumn{5}{|c|}{ Model 2} & \\
\hline & intercept & $\begin{array}{c}\text { insufficient } \\
\text { domestic } \\
\text { demand }\end{array}$ & $\begin{array}{l}\text { uncertainty } \\
\text { of economic } \\
\text { environment }\end{array}$ & $\begin{array}{l}\text { financial } \\
\text { problems }\end{array}$ & $\begin{array}{l}\text { unclear legal } \\
\text { regulations }\end{array}$ & $\mathrm{R}^{2}$ \\
\hline Small & $\begin{array}{l}-0.050 \\
(0.462)\end{array}$ & $\begin{array}{c}-0.406^{* * *} \\
(144)\end{array}$ & $\begin{array}{l}-0.089 \\
(0.118)\end{array}$ & $\begin{array}{c}-1.191 * * * \\
(0.257)\end{array}$ & $\begin{array}{c}0.835 * * * \\
(0.198)\end{array}$ & 0.54 \\
\hline Medium-sized & $\begin{array}{l}-0.112 \\
(0.405)\end{array}$ & $\begin{array}{c}-0.473 * * * \\
(0.114)\end{array}$ & $\begin{array}{c}-0.222 * * \\
(0.094)\end{array}$ & $\begin{array}{c}-0.682 * * * \\
(0.189)\end{array}$ & $\begin{array}{c}0.762 * * * \\
(0.162)\end{array}$ & 0.64 \\
\hline Large & $\begin{array}{l}-0.274 \\
(0.537)\end{array}$ & $\begin{array}{c}-0.492 * * * \\
(0.149)\end{array}$ & $\begin{array}{c}-0.265 * * * \\
(0.093)\end{array}$ & $\begin{array}{c}-0.780 * * \\
(0.339)\end{array}$ & $\begin{array}{c}0.524 * * * \\
(0.183)\end{array}$ & 0.46 \\
\hline
\end{tabular}

Notes: standard errors are reported in parentheses. *,**,*** indicates significance at the $10 \%, 5 \%$, and $1 \%$ level, respectively.

Source: authors' calculations.

The analysis of the statistical significance of parameters indicates that for small enterprises model 1 best describes the impact of business barriers on the assessment of the current economic situation. Model 1 and model 2 are equally good for medium-sized enterprises, and model 2 is the best description of the examined relationship for large enterprises.

\section{Conclusions}

The study showed that statistically significant barriers to economic activity in all specified areas that affect the assessment of the general current economic situation by entrepreneurs can be determined. These barriers are: insufficient domestic and foreign demand (demand area), shortage of skilled labour (supply area), financial problems, unclear legal regulations, uncertainty of economic environment (financial and legal area). The impact strength varies within the size groups of enterprises. The relationship is the weakest in large enterprises. As one might expect, they are most resistant to changes in the economic environment.

There was no statistically significant relationship between the perception of the barriers and the assessment of the expected general economic situation. Perhaps this is due to the fact that the questions about the barriers and the assessment of the current general economic 
situation are in the same part of the questionnaire used by the CSO in the business tendency survey (the questions about the assessment of the expected general economic situation are in the second part). It is quite remarkable that entrepreneurs so poorly include their perception of the barriers in assessing the expected economic situation, especially that these expectations concern the situation in just the next three months. Thus, the consistency of the opinions of entrepreneurs about the business climate assessments may be questionable, taking also into account the fact that there are the barriers with high intensity but uncorrelated with the assessment of the economic situation (e.g. high payments to state revenue). It would be advisable to place the questions about the barriers in the both parts of the questionnaire thus the entrepreneurs could differentiate between the barriers for the current and expected economic activity. Another solution could be to indicate which barriers are of the long-term type - these (especially financial and legal barriers, see Figure 5) could be presumably more related to the expected activity. We believe that these changes could help in identifying the barriers influencing the expected economic activity. This would give more solid ground for building the application element of the study both for the policy makers (to apply the right policy tools for removing or mitigating the barriers) and for the business organizations (to optimize their business planning).

The interesting and optimistic conclusion is that in the years 2003-2019 there was an overall decrease in the perception of the barriers hindering the business activity in manufacturing enterprises in Poland with minor exceptions (shortage of total and skilled labour and costs of labour). The number of enterprises assessing that they operate without barriers has been steadily growing.

\section{References}

Adamowicz, E., Jóźwiak, J. (2008). Ograniczenia aktywności przedsiębiorstw. Prace i Materiaby IRG SGH, 80, 157-179.

Fazlagić, J., Skikiewicz, R. (2018). Analiza kształtowania się barier prowadzenia działalności w wybranych działach sektora usług w świetle zmian klimatu koniunktury w województwach Polski. Prace Komisji Geografii Przemystu Polskiego Towarzystwa Geograficznego, 32 (2), 216-228. DOI: 10.24917/20801653.322.15.

Grant Thornton (2019). Bariery w biznesie. Edycja 2019. Retrieved from: https://grantthornton. pl/wp-content/uploads/2019/05/Bariery-w-biznesie.-Edycja-2019.pdf. 
Gruszecki, T. (2002). Współczesne teorie przedsiębiorstwa. Warszawa: Wydawnictwo Naukowe PWN.

GUS (2018). Zeszyt metodologiczny. Badanie koniunktury gospodarczej. Retrieved from:

https://stat.gov.pl/obszary-tematyczne/koniunktura/koniunktura/badanie-koniunktury-gospodarczej-zeszyt-metodologiczny,5,9.html.

GUS (2019). Koniunktura w przetwórstwie przemystowym, budownictwie, handlu i usługach 2000-2019. Retrieved from: https://stat.gov.pl/obszary-tematyczne/koniunktura/koniunktura/koniunktura-w-przetworstwie-przemyslowym-budownictwie-handlu-i-uslugach-2000-2019-kwiecien-2019,4,24.html (April 2019).

Komorowski, J. (2012). Cele przedsiębiorstwa a rozwój gospodarczy. Ujęcie behawioralne. Warszawa: Oficyna Wydawnicza Szkoła Główna Handlowa w Warszawie.

Konfederacja Lewiatan (2018). Raport z badania nastrojów przedsiębiorców. Retrieved from: konfederacjalewiatan.pl > Raport_z_badania_natroj_w_przedsi_biorc_w.

Krezymon, M. (2018). Determinanty rozwoju przedsiębiorstw sektora MSP. Współczesne Problemy Ekonomiczne, 2 (18), 23-31. DOI: 10.18276/wpe.2018.18-03.

Leoński, W. (2014). Bariery funkcjonowania małych i średnich przedsiębiorstw w Polsce. Zeszyty Naukowe Wydziału Nauk Ekonomicznych Politechniki Koszalińskiej, 18, 95-108.

Mikołajczyk, P., Skikiewicz, R. (2014). Bariery prowadzenia działalności jako determinanty sytuacji finansowej przedsiębiorstw sektora budowlanego. Studia Ekonomiczne, 3 (LXXXII), 361-380.

NBP (2019). Szybki Monitoring NBP. Analiza sytuacji sektora przedsiębiorstw. Retrieved from: https://www.nbp.pl/home.aspx?c=/ascx/koniunktura_prezentacja.ascx (January 2019).

Oryńczak, J., Święcka, M., Walkowska, K., Zagoździńska, I. (2008). Bariery działalności przedsiębiorstw w Polsce w świetle badań koniunktury gospodarczej prowadzonych przez GUS. Prace i Materiaty IRG SGH, 80, 181-197.

Ziemba, M., Świeszczak, K. (2013). Bariery rozwoju podmiotów z sektora MSP - ze szczególnym uwzględnieniem możliwości pozyskania kapitału obcego. Zeszyty Naukowe Uniwersytetu Szczecińskiego. Finanse, Rynki Finansowe, Ubezpieczenia, 64/1, 491-499.

ZPP (2018a). Busometr. Wyniki półroczne, wrzesień 2018. Retrieved from: https://zpp. net.pl/wp-content/uploads/2018/09/MP_Busometr_po\%CC\%811roczne-wyniki_ wrzesien\%CC\%81-2018.pdf.

ZPP (2018b). Bariery prowadzenia działalności gospodarczej w Polsce. Retrieved from https:// zpp.net.pl/wp-content/uploads/2018/02/BarierydlaMSPwPL.pdf. 